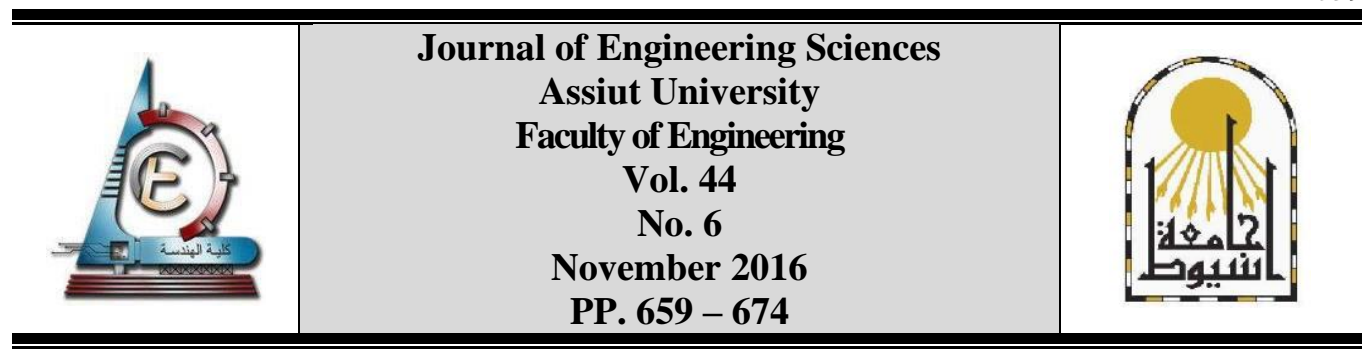

\title{
COMPARISON BETWEEN SINGLE AND DOUBLE ANCHORED SHEET PILES WITH SIMPLIFIED APPROACHES TO SOLVE THE STATICALLY INDETERMINATE SYSTEMS
}

\author{
Dina A. Emarah ${ }^{1}$ and Safwat A. Seleem ${ }^{2}$ \\ ${ }^{1}$ Construction Research Institute, National Water Research Center, \\ Ministry of Water Resources and Irrigation, Egypt \\ ${ }^{2}$ High Institute of Engineering, $15^{\text {th }}$ May City
}

Received 12 July 2016; Accepted 14 August 2016

\begin{abstract}
The paper studied a case of anchored sheet piles that exposed to surcharge loads at different distances from the wall. Experimental works were conducted on two different systems of single and double anchored sheet pile walls. Also, numerical simulations were performed on both systems using PLAXIS. The experimental and numerical results were compared. The comparison showed the advantages of using double anchored sheet pile instead of single anchored one. It was found that a large reduction occurred in the values of maximum bending moments in the double anchored system, in addition to a significant reduction in the values of anchor forces. This paper also produced three simplified approaches aiming to solve the statically indeterminate system of double anchored sheet pile exposed to surcharge loads placed at different distances from the sheet pile wall.
\end{abstract}

Keywords: Sheet Pile, Anchor, Single, Double, Comprehensive Comparison.

\section{Introduction}

Various studies were performed to evaluate the behavior of sheet pile walls. Finite element method (FEM) was utilized for the analysis of anchored sheet pile walls [1] [2] [3] [4] [5]. These studies did not care about the using of a double anchored sheet pile instead of single anchored one. In addition, these studies ignored the effect of surcharge loads put at different distances from the sheet pile walls on the design. This study concentrated on the assessment of the double anchored sheet pile behavior compared with that of the single anchored system in the presence of surcharge loads put at different distances from the sheet pile wall. Accordingly, this study included experimental works and numerical simulations on the two different systems. Furthermore, a comprehensive experimental and numerical comparison between the two systems of single and double anchored sheet piles was performed. These approaches produced simplified methods to design double anchored sheet pile system exposed to surcharge loads put at different distances from the sheet pile wall.

\section{Testing apparatus and sheet pile model}

Experimental works were conducted at the laboratories of Faculty of Engineering, Cairo University. Figure 1 illustrates the apparatus and the sheet pile model used in the 
experimental work. The container filled with fine loose sand having unit weight $(\gamma)$ equal 1.5 $\mathrm{gm} / \mathrm{cm}^{3}$ and average angle of shear resistance $(\varphi)$ of about $30^{\circ}$. The soil was used to be loose and fine sand and the container was polished internally and externally to minimize the side friction that may be developed between the container and the soil [6]. The sand was deposited into the container in a loose state in horizontal layers. Each layer was $10 \mathrm{~cm}$ thick. In order to control the uniformity and density of the deposited sand, a plastic funnel has been used in the pouring process of sand from a height of $20 \mathrm{~cm}$. When the surface of the deposited sand reached the level of wall anchors, the waling was placed and anchor rods were installed. All anchor rods have been installed without fixation with tank side to simulate the probable condition in the field. In addition, the installation of anchor rods was carried out without prestressing. The necessary adjustment has been adopted to keep the anchor rods in their horizontal levels and also to keep the anchor plates in their vertical position.

After completing the installation process of anchor rods, the process of sand deposition was continued above the position of anchor rods until reaching the top level of sand in case of single anchored sheet pile wall, or until reaching the level of upper anchor rod in case of double anchored sheet pile wall. The same procedure for anchor rod installation and sand deposition process was applied in case of double anchored sheet pile wall.

A straight spatula was used gently to level the sand surface. The average filling time was about seven hours. The filling process was conducted simultaneously on both sides of the sheet pile model.

In like manner, the relative density (Dr) of the tested sample was found to be $33 \%$. In this manner, the utilized sand is considered to be loose sand as (Dr) lies between 15 and 35\% [7]. The dimensions of the container were chosen in order to minimize the probable side friction between the sides of the tank and the adjacent sand. The sheet pile model was designed to simulate the prototype sheet pile of Type Larsen II. The condition of similarity between the model and the prototype was built on the flexibility number $(\rho)$ which should be the same for both of them [8].

$$
\rho=10.91 * 10^{-7}\left(\mathrm{H}^{4} / \mathrm{EI}\right)
$$

Where: $\mathrm{H}$ is in meter, $\mathrm{E}$ is Young's modulus of the sheet pile material in $\mathrm{MN} / \mathrm{m}^{2}$, I is the moment of inertia of the sheet pile section in $\mathrm{m}^{4} / \mathrm{m}^{`}$ and $10.91 * 10^{-7}$ is the constant value.

The aforementioned Equation is not a dimensionally homogeneous equation unless the constant is in $\mathrm{MN} / \mathrm{m}^{2} / \mathrm{m}^{\prime}$ [9]. Therefore, for similarity, equating, $\rho$, model to, $\rho$, prototype yields:

$$
\left(\mathrm{H}^{4} / \mathrm{EI}\right)_{\text {model }}=\left(\mathrm{H}^{4} / \mathrm{EI}\right)_{\text {prototype }}
$$

The conventional Rankine's theory of earth pressure, in addition to the simple $45^{\circ}$ distribution strip load method, were applied in computing the dimensions of the anchored sheet pile model elements, such as anchor diameter, waling, and anchor plate. The angle of shear resistance of the sand $(\varphi)$ was determined from the direct shear box test [10].

The surcharge loads in the experiments are applied via uniform rectangular steel sheet plates (Fig. 2) having a length of $59 \mathrm{~cm}$ and a width of $16 \mathrm{~cm}$. Each plate exerts a uniform pressure on the soil surface of about $1 \mathrm{kN} / \mathrm{m}^{2}$. And the maximum surcharge load is 10 $\mathrm{kN} / \mathrm{m}^{2}$. The surcharge loads were placed on the backfill surface such that the free distance between the edge of the steel plates and the sheet pile wall varied as $h / 6, h / 3,0.5 \mathrm{~h}, 2 \mathrm{~h} / 3, \mathrm{~h}$, $1 \frac{1}{3} \mathrm{~h}$, and $2 \mathrm{~h}$. The length of anchor rod is $60 \mathrm{~cm}$ away from the sheet pile wall model to constitute the minimum required length of the anchor rods [11]. The anchor rod diameter was selected to be $0.9^{*} 10^{-3} \mathrm{~m}$. The horizontal spacing between anchor rods $(\mathrm{S})$ was chosen 
Dina A. Emarah et al., Comparison between single and double anchored sheet piles with ...........

to have a value of $8 \mathrm{~cm}$, which simulates a distance of about $2.5 \mathrm{~m}$ in the field. The anchor rods were installed horizontally at a depth of about $0.25 \mathrm{~h}(7.50 \mathrm{~cm})$ below the ground surface of the tested sand. The sheet pile model was temporally held in place vertically during filling and removal of sand from the container.

In order to determine the distribution of bending moment along the total height of the sheet pile model, ten electrical strain gauges were installed along the wall height as shown in Figure 3. The positions of these strain gauges were selected according to the expected bending moment along the height of the wall model. The positions of these strain gauges are shown in front of each symbols group of bending moments as shown in Figure 4. Similarly, two strain gauges were glued on the anchor rods. These strain gauges were used to measure the anchor force in both the single anchored and the double anchored sheet pile systems. Dial gauges were hanged vertically from a vertical steel bar, which in turn, was connected to a horizontal steel bar. The horizontal steel bar was firmly supported on the vertical sides of the container. The dial gauges were used to measure the horizontal displacements of the sheet pile model during the experiments.

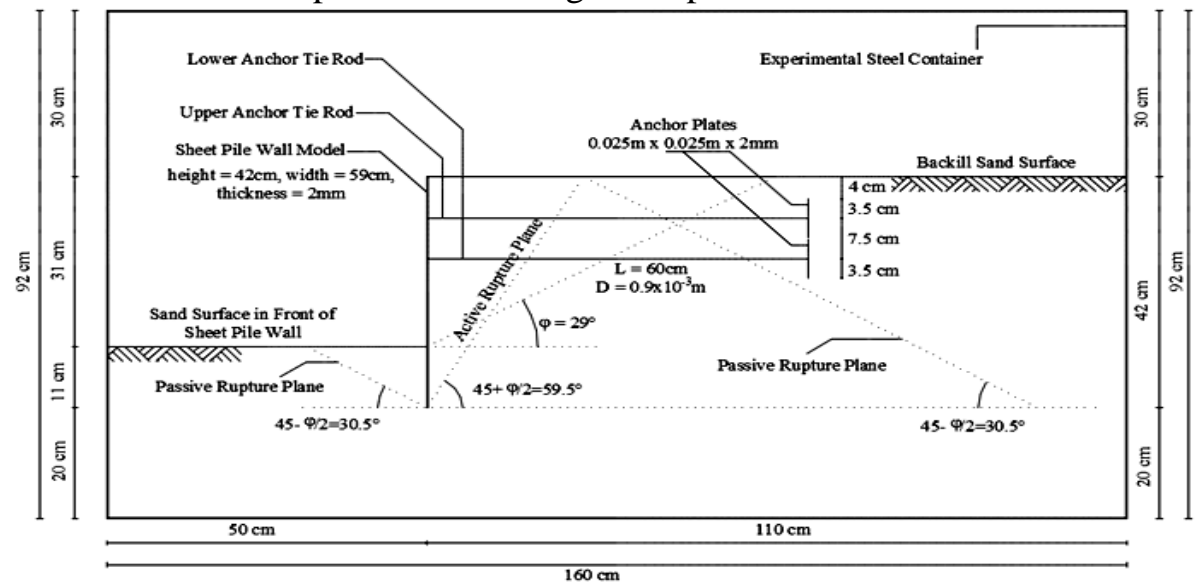

(a) Anchored Sheet Pile Model in Container

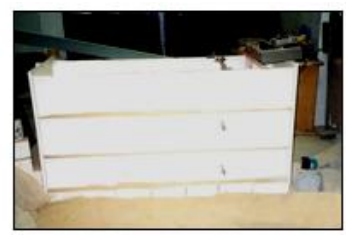

(b) Container Model

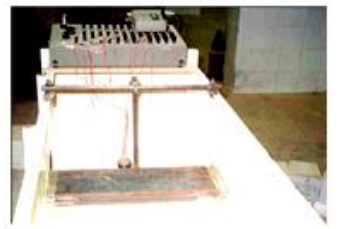

(c) Read-out Unit, Strain Transducer Set, Dial Gauges, Vertical and Horizontal Bars, Surcharge Loads

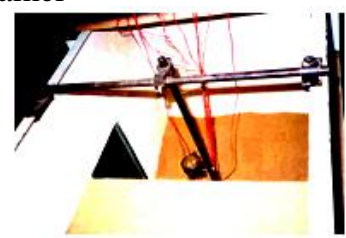

(d) Horizontal and Vertical Steel Bars Used for Hanging Dial Gauges

Fig. 1. Detail of Anchored Sheet Pile Model in Container and Equipment Used in Experimental Work

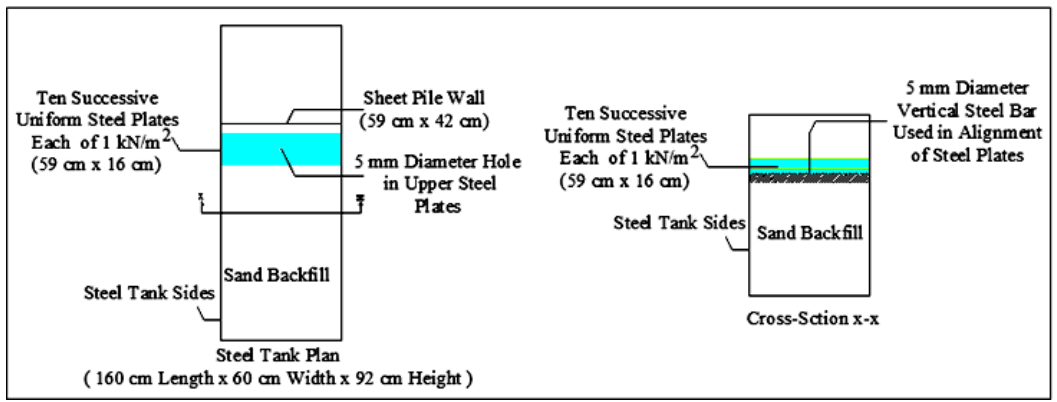

Fig. 2. Uniform Steel Sheet Plates Used As Surcharge Loads Acting on Sand Backfill 


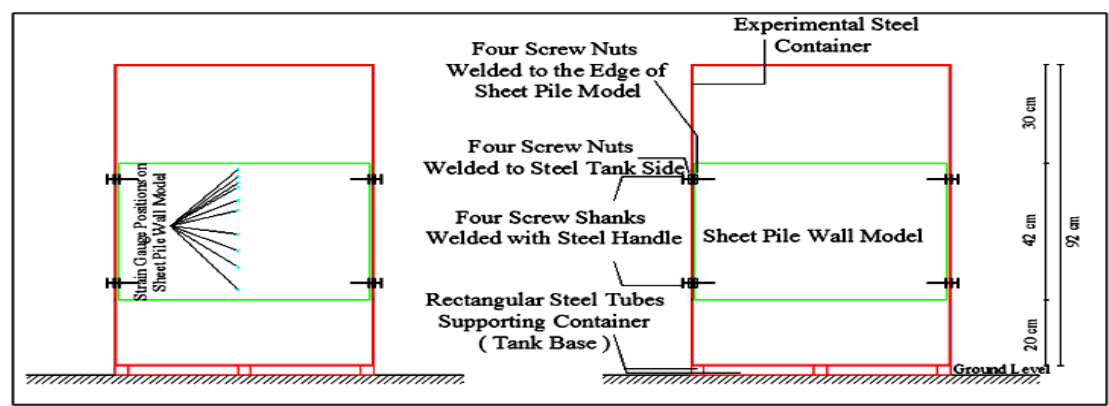

Fig. 3. The Positions of Strain Gauges

\section{Critical dredging height of single anchored sheet pile}

While the single anchored sheet pile was standing in its stationary position, the filling process of the tank was executed. Upon reaching the upper level of sand on both sides of the sheet pile wall and leveling its upper surface, all screw shanks were simultaneously loosened. At this stage the wall was slightly dislocated horizontally and vertically. The soil in front of the wall was then shoveled away in stages. The developed stresses in the sheet pile wall, the induced anchor forces, and the horizontal wall displacements were monitored and compared with the permitted values. The purpose of monitoring the different stress and displacement values at each stage of the dredging process was to ensure the stability of structure.

For instance, the maximum allowable stress in steel is about $1400 \mathrm{~kg} / \mathrm{cm}^{2}$ and the permitted values were selected to be not exceeding $50 \%$ to $60 \%$ of this value. The stable dredging height was found to be $0.31 \mathrm{~m}$ as shown in Figure 1 (a). For convince we can consider the free height to be $0.3 \mathrm{~m}$.

\section{Numerical work}

A Finite element computer program PLAXIS, has been used in this study to analyse both systems of single and double anchored sheet piles. The type that has been used in this study was the plane-strain model. In this study, the sheet pile walls and anchor plates are simulated within the geometry model as beams after calculating the flexural rigidity (EI) and axial stiffness (EA) for each of them. For the sheet pile wall, the axial stiffness, EA, was calculated as $2.36^{*} 10^{-5} \mathrm{kN} / \mathrm{m}$ and its flexural rigidity (EI) had a value of $0.079 \mathrm{kNm} / \mathrm{m}$ !

As for the anchor plates of the upper and the lower anchor rods, EA was found to be $1 * 10^{-4} \mathrm{kN} / \mathrm{m}$, EI was found to be $3.3^{*} 10^{-3} \mathrm{kNm} / \mathrm{m}$. The value of Poisson's ratio $(\mathrm{v})$ for concrete was taken as 0.1 and was taken as 0.15 for steel. The anchor rods have been simulated in the model as springs. These springs are used to model ties between two points. The line connecting between these two points is called an elastic node-to-node anchor with a constant stiffness. The axial stiffness (EA) for anchor rods was found to be $127.2 \mathrm{kN} / \mathrm{m}$. The horizontal distance, $\mathrm{L}_{\text {spacing, }}$, between each two adjacent anchors and the axial stiffness (EA) are assigned in the material database of the geometry model. As for the modeling of soil, the type of soil used in the experimental work was modeled as loose fine sand, its modulus of elasticity and Poisson's ratio were taken as $104 \mathrm{kN} / \mathrm{m}^{2}$ and 0.3 , respectively. The friction angle was found to have an average value of $29^{\circ}$ according to direct shear test results. In most cases, the angle of dilatancy $\psi$ is of zero value for soils that have friction angles less than $30^{\circ}$. Hence, $\psi$ was chosen to be of zero value. The value of intercept (c) was chosen to be $0.15 \mathrm{kN} / \mathrm{m}^{2}$ in order to avoid complications in running the program. As there is no water used in the experiments, the permeability values in both direction, $\mathrm{Kx}$ and $\mathrm{Ky}$, were of zero 
values. The dry unit weight, $\gamma_{\text {dry }}$, of sand was computed experimentally and found to be 15 $\mathrm{kN} / \mathrm{m}^{3}$ and the wet unit weight $\left(\gamma_{\text {wet }}\right)$ was assumed to be $15.5 \mathrm{kN} / \mathrm{m}^{3}$.

\section{Experimental and numerical results}

Figure 4 illustrates the distribution of bending moments developed experimentally and numerically in single anchored and double anchored sheet piles after placing a surcharge of 10 $\mathrm{kN} / \mathrm{m}^{2}$ at a free distance of $\mathrm{h} / 6(5 \mathrm{~cm})$ from the wall. Figure 5 shows all maximum bending moment values obtained experimentally and numerically in single and double anchored sheet pile walls. Figure 5 indicates the similar general trends between the experimental and the numerical results in case of single anchored system, especially when the surcharge load exceeds $5 \mathrm{kN} / \mathrm{m}^{2}$. Also, in case of double anchored system, it illustrates a high degree of agreement between the experimental and the numerical results.

In case of single anchored sheet pile, the maximum values of the bending moments computed numerically are higher than those resulting from the experimental work in general, except for relatively small values of surcharge placed close to the sheet pile wall. However, after placing the surcharge loads at free distances of $\mathrm{h}(30 \mathrm{~cm})$ or more, the numerical and experimental values became close to each other and the difference between them was insignificant. In case of double anchored sheet pile, there is a high degree of similarity between the experimental and the numerical results, as the curves relating the maximum bending moment in double anchored sheet pile wall to the surcharge value in both cases are almost identical.

The achievement of a significant reduction in maximum bending moment values developed in the sheet pile wall has been proved experimentally and numerically by using a double anchored sheet pile system instead of a single anchored one. Figure 6 exhibits the percentages of reduction in maximum bending moment achieved experimentally and numerically in this case. The numerical and experimental reductions are close to each other.

Experimentally, the maximum reductions reached $81.8 \%$ and $80 \%$ after placing a surcharge value of $10 \mathrm{kN} / \mathrm{m}^{2}$ at free distances of $\mathrm{h} / 6$ and $\mathrm{h} / 3(5$ and $10 \mathrm{~cm})$, respectively. The lowest reduction was about $37 \%$ after placing the same surcharge value of $10 \mathrm{kN} / \mathrm{m}^{2}$ at a free distance of the free height $\mathrm{h}(30 \mathrm{~cm})$. Numerically, the reductions were $83.67 \%$ and $84.38 \%$ obtained after placing a surcharge value of $10 \mathrm{kN} / \mathrm{m}^{2}$ at free distances of $\mathrm{h} / 6$ and $\mathrm{h} / 3(5$ and $10 \mathrm{~cm})$, respectively, whereas the lowest reduction was $35.6 \%$, obtained after placing the same surcharge at the free distance of the free height $\mathrm{h}(30 \mathrm{~cm})$.
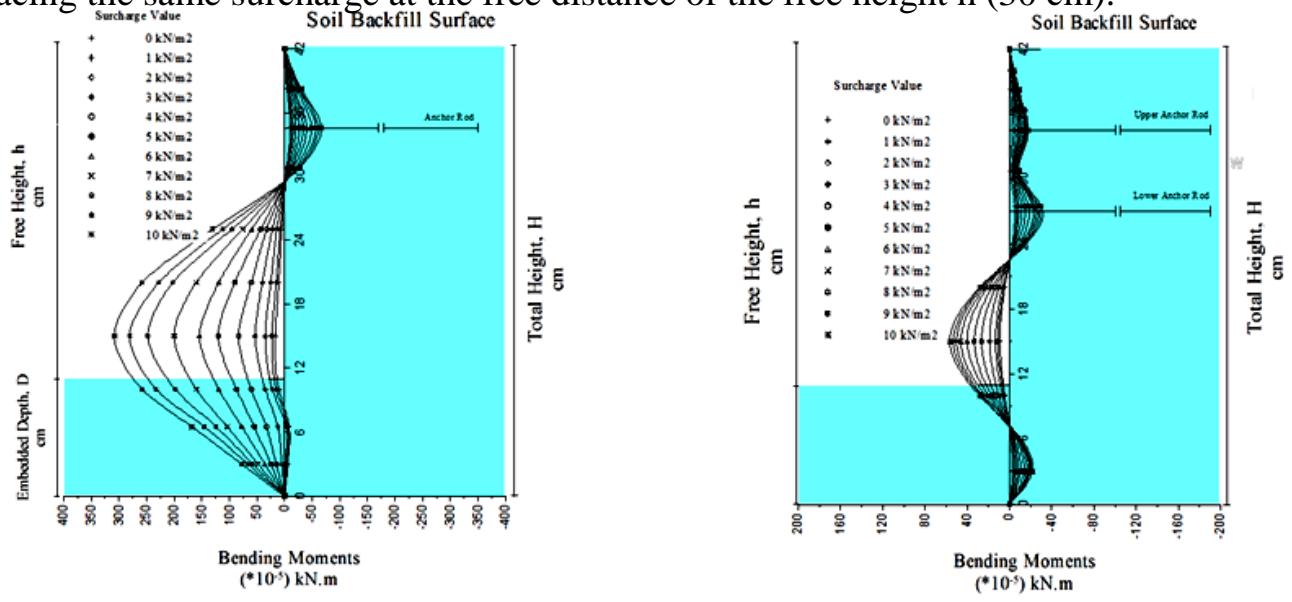

(a) Bending Moments Measured Experimentally in Single Anchored Sheet Pile

(b) Bending Moments Measured Developed in Double Anchored Sheet Pile 


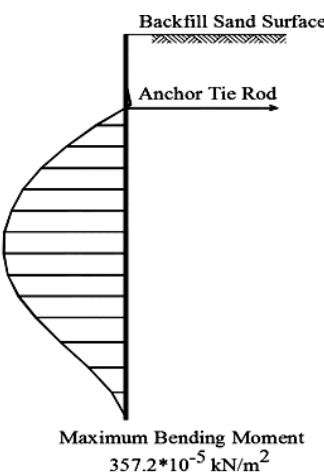

$357.2 * 10^{-5} \mathrm{kN} / \mathrm{m}^{2}$

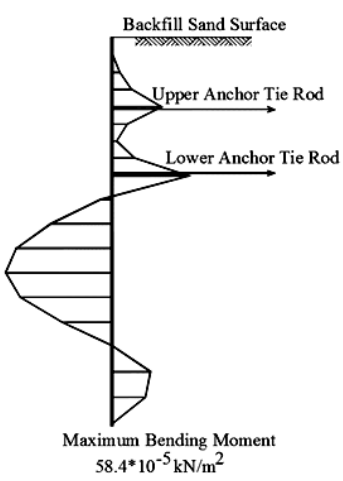

(d) Numerical Bending Moments Distribution in Double Anchored Sheet Pile Wall (Surcharge $=10 \mathrm{kN} / \mathrm{m}^{2}$ ) (c) Numerical Bending Moments Distribution in Single Anchore Sheet Pile Wall (Surcharge $=10 \mathrm{kN} / \mathrm{m}^{2}$ )

Fig. 4. Bending Moments Measured Experimentally and Numerically in Single and Double Anchored Sheet Pile after Placing Surcharge at a Free Distance of h/6 $(5 \mathrm{~cm})$ from Sheet Pile Wall
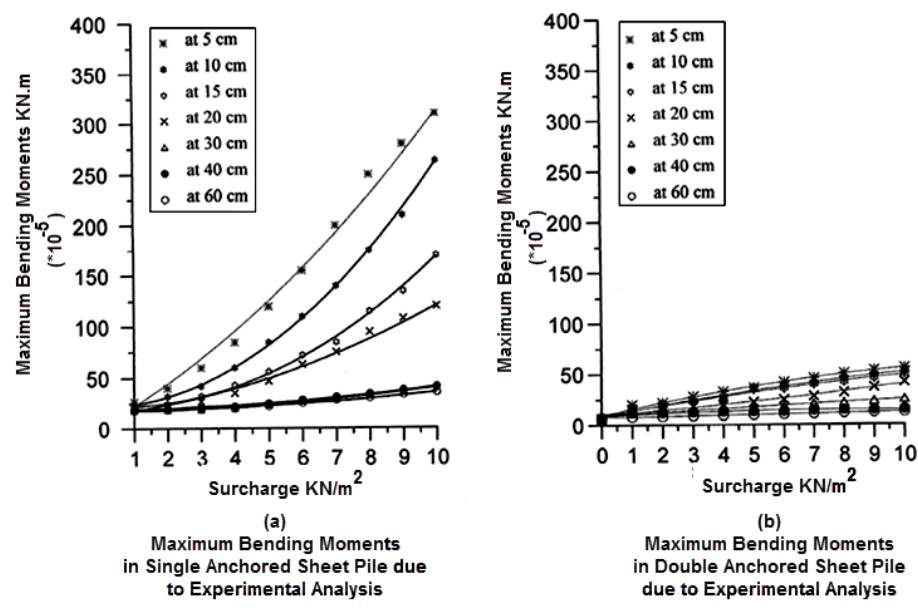

(b)

Maximum Bending Moments

in Double Anchored Sheet Pile

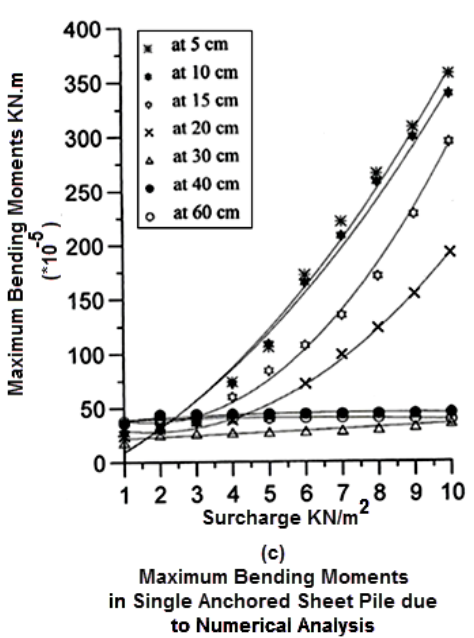

due to Experimental Analysis

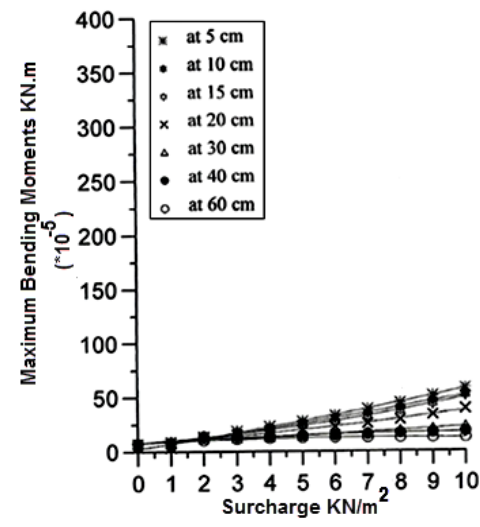

(d)

Maximum Bending Moments in Double Anchored Sheet Pile due to Numerical Analysis

Fig. 5. Comparison between Maximum Bending Moment Values Included In Single Anchored and Double Anchored Sheet Piles According To Experimental Work and Numerical Analysis 


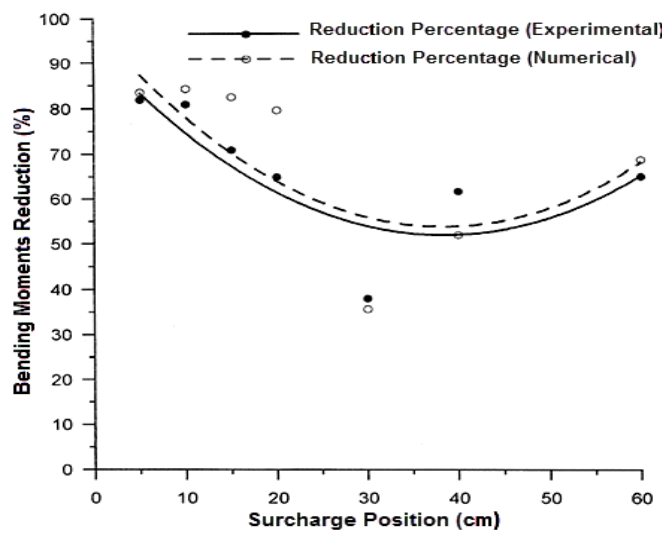

Fig. 6. Reduction in Maximum Bending Obtained Experimentally and Numerically by Using Double Anchored Sheet Pile instead of single Anchored Sheet Pile

For a convenient comparison, the numerical and experimental results of anchor forces developed in both the single anchored and the double anchored systems were plotted in Figure 7 and Figure 8. These Figures confirm that the anchor forces developed in single anchored system are always higher than those developed in either the upper or lower anchor rod in double anchored system. Moreover, the forces developed in the lower anchor rods are always higher than those developed in the upper anchor rods. This is may be due to the higher value of the active earth pressure acting on the lower anchor rod than that acting on the lower one. These results are valid in all cases of surcharge loading. Table 1 shows the ratio obtained experimentally between the upper and the lower anchor forces induced in double anchored sheet pile in all cases of surcharge loading. Also, this Table illustrates the experimental ratio between the lower anchor force in double anchored sheet pile and that developed in single anchored system in all cases of surcharge loading.

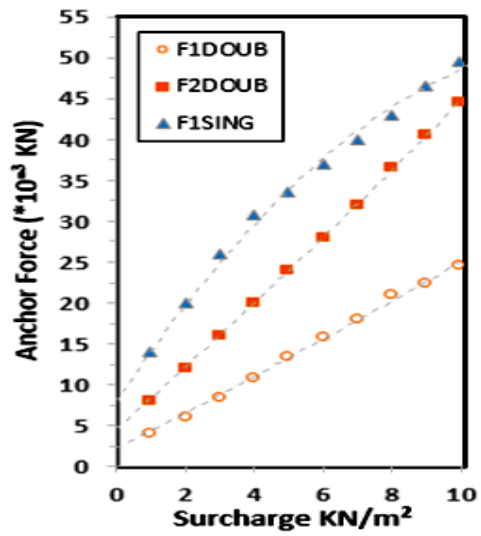

Numerically

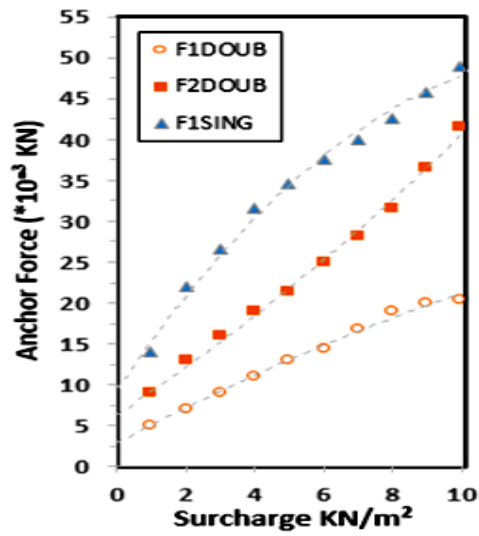

Experimentally

(a) $5 \mathrm{~cm}$ from Wall 


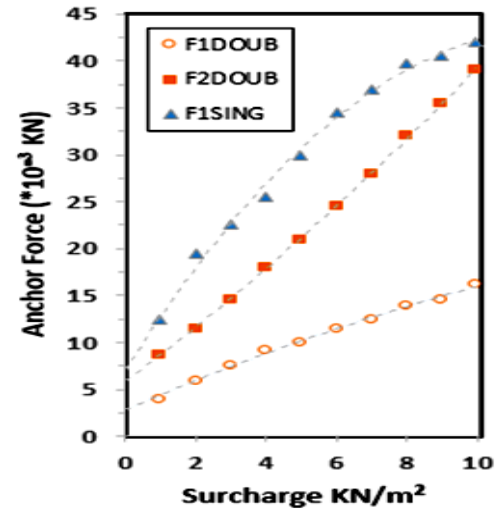

Numerically

(b) $20 \mathrm{~cm}$ from Wall

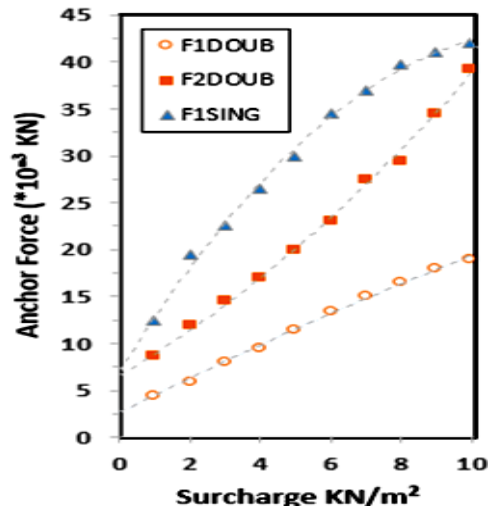

Experimentally

Fig. 7. Anchored Forces Obtained Numerically and Experimentally in Single and Double Anchored Sheet Piles after Placing Surcharge Loads at a Free Distance of (a) $5 \mathrm{~cm}$ and (b) $20 \mathrm{~cm}$ from Wall

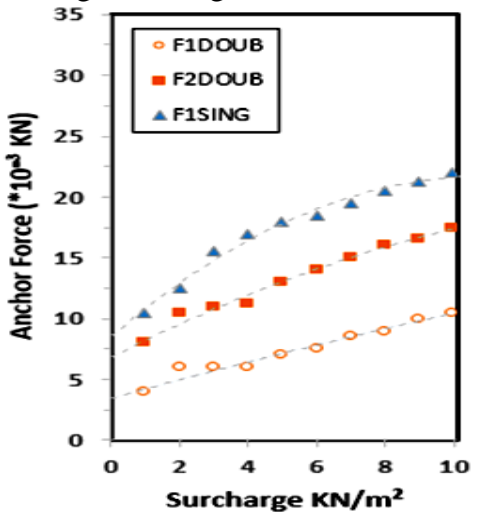

Numerically

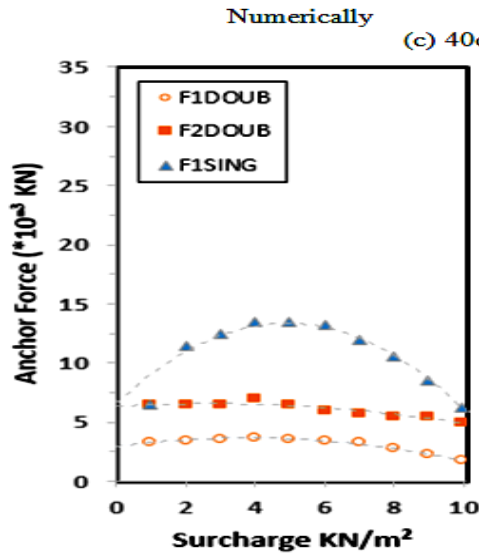

Numerically

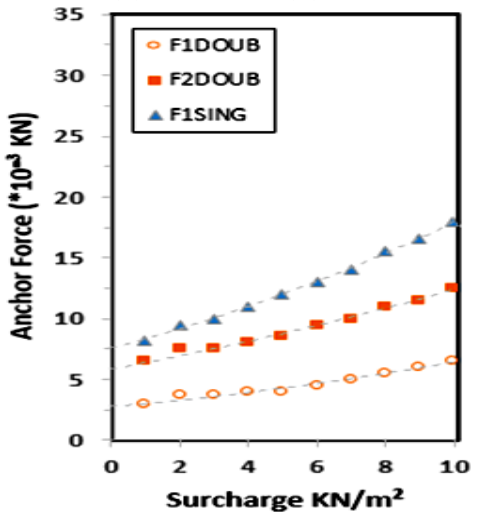

Experimentally

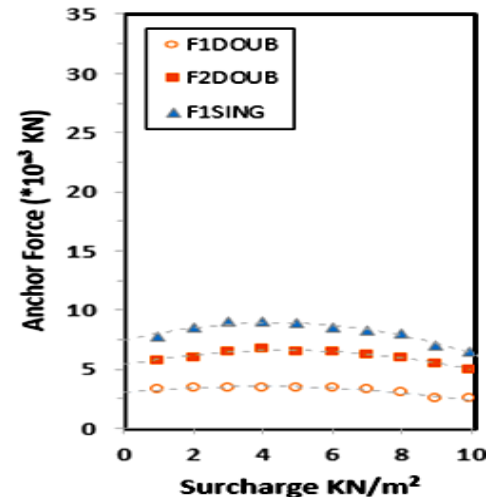

Experimentally

(d) $60 \mathrm{~cm}$ from Wall

Fig. 8. Anchored Forces Obtained Numerically and Experimentally in Single and Double Anchored Sheet Piles after Placing Surcharge Loads at a Free Distance of (c) $40 \mathrm{~cm}$ and (d) $60 \mathrm{~cm}$ from Wall 
Dina A. Emarah et al., Comparison between single and double anchored sheet piles with

Table 1.

Ratio between Upper and Lower Anchor Forces Induced in Double Anchored Sheet Pile and that developed in Single after Placing Surcharge Loads at Different Distances from Wall

\begin{tabular}{|c|c|c|c|c|c|c|c|c|c|c|c|}
\hline \multirow{2}{*}{$\begin{array}{c}1 \mathrm{DOUB} / \mathrm{F}_{2 \mathrm{DOU}} \\
\mathrm{B}\end{array}$} & \multicolumn{5}{|c|}{ Surcharge Values $\mathrm{kN} / \mathrm{m}^{2}$} & \multirow{2}{*}{$\begin{array}{c}\mathrm{F}_{2 \mathrm{DOUB}} / \mathrm{F}_{1 \mathrm{SIN}} \\
\mathrm{G}\end{array}$} & \multicolumn{5}{|c|}{ Surcharge Values $\mathrm{kN} / \mathrm{m}^{2}$} \\
\hline & $1-2$ & $3-4$ & $5-6$ & $7-8$ & $9-$ & & $1-2$ & $3-4$ & $5-6$ & $7-8$ & $9-10$ \\
\hline $5 \mathrm{~cm}(\mathrm{~h} / 6)$ & 0.4 & 0.5 & 0.6 & 0.5 & 0.50 & $5 \mathrm{~cm}(\mathrm{~h} / 6)$ & 0.59 & 0.59 & 0.66 & 0.74 & 0.84 \\
\hline Average & \multicolumn{5}{|c|}{0.53} & Average & \multicolumn{5}{|c|}{0.69} \\
\hline $10 \mathrm{~cm}(\mathrm{~h} / 3)$ & 0.4 & 0.5 & 0.5 & 0.5 & 0.50 & $10 \mathrm{~cm}(\mathrm{~h} / 3)$ & 0.62 & 0.57 & 0.67 & 0.75 & 0.83 \\
\hline Average & \multicolumn{5}{|c|}{0.53} & Average & \multicolumn{5}{|c|}{0.69} \\
\hline $15 \mathrm{~cm}(0.5$ & 0.4 & 0.4 & 0.4 & 0.3 & 0.36 & $15 \mathrm{~cm}(0.5$ & 0.49 & 0.49 & 0.53 & 0.59 & 0.69 \\
\hline Average & \multicolumn{5}{|c|}{0.40} & Average & \multicolumn{5}{|c|}{0.56} \\
\hline $20 \mathrm{~cm}$ & 0.4 & 0.4 & 0.4 & 0.3 & 0.35 & $20 \mathrm{~cm}(2 \mathrm{~h} / 3)$ & 0.47 & 0.50 & 0.52 & 0.55 & 0.71 \\
\hline Average & \multicolumn{5}{|c|}{0.40} & Average & \multicolumn{5}{|c|}{0.55} \\
\hline $30 \mathrm{~cm}(\mathrm{~h})$ & 0.5 & 0.5 & 0.5 & 0.4 & 0.40 & $30 \mathrm{~cm}(\mathrm{~h})$ & 0.55 & 0.51 & 0.49 & 0.60 & 0.74 \\
\hline Average & \multicolumn{5}{|c|}{0.48} & Average & \multicolumn{5}{|c|}{0.58} \\
\hline $40 \mathrm{~cm}\left(1 \frac{1}{3}\right.$ & 0.4 & 0.4 & 0.4 & 0.5 & 0.53 & $40 \mathrm{~cm}\left(1 \frac{1}{3}\right.$ & 0.79 & 0.72 & 0.72 & 0.71 & 0.70 \\
\hline Average & \multicolumn{5}{|c|}{0.49} & Average & \multicolumn{5}{|c|}{0.76} \\
\hline $60 \mathrm{~cm}(2 \mathrm{~h})$ & 0.5 & 0.5 & 0.5 & 0.4 & 0.46 & $60 \mathrm{~cm}(2 \mathrm{~h})$ & 0.64 & 0.74 & 0.78 & 0.80 & 0.77 \\
\hline Average & \multicolumn{5}{|c|}{0.51} & Average & \multicolumn{5}{|c|}{0.75} \\
\hline A.R. All & \multicolumn{5}{|c|}{0.48} & A.R. All & \multicolumn{5}{|c|}{0.65} \\
\hline
\end{tabular}

It was deduced from Table 1 the following:

$$
\begin{aligned}
& \frac{F_{1 \text { DOUB }}}{F_{2 \text { DOUB }}}=0.48 \\
& \frac{F_{2 \text { DOUB }}}{F_{\text {ISING }}}=0.65
\end{aligned}
$$

Where:

$\mathrm{F}_{1 \mathrm{DOUB}}:$ is the average force induced in the upper anchor rod in the double anchored system.

$\mathrm{F}_{2 \mathrm{DOUB}}:$ is the average force induced in the lower anchor rod in the double anchored system.

$\mathrm{F}_{\text {ISING }}:$ is the average force in the anchor rod in single anchored system

From Equations (1) and (2), it could be concluded that:

$$
\mathrm{F}_{1 \mathrm{DOUB}}=0.312 \mathrm{~F}_{1 \mathrm{SING}}
$$

Accordingly, the following relationship could be assumed:

$$
\mathrm{F}_{1 \text { DOUB }}+\mathrm{F}_{2 \text { DOUB }} \approx \mathrm{F}_{1 \text { SING }}
$$

Similarly, the ratio computed numerically between the upper and the lower anchor forces in the double anchored sheet pile in addition to the ratio between the lower anchor force in double anchored sheet pile and that developed in single anchored system in all cases of surcharge loading were computed numerically as follows: 


$$
\begin{aligned}
& \frac{F_{1 \text { DOUB }}}{F_{2 \text { DOUB }}}=0.51 \\
& \frac{F_{\text {2DOUB }}}{F_{1 \text { SING }}}=0.69
\end{aligned}
$$

Accordingly, the following relationship is obtained:

$\mathrm{F}_{1 \mathrm{DOUB}}+\mathrm{F}_{2 \mathrm{DOUB}}=1.04 \mathrm{~F}_{1 \mathrm{SING}}$

This relationship is close to that obtained experimentally (Equation 3). Consequently, the cross section of the anchor rod in case of single anchored system is slightly higher than the sum of cross sections of the upper and the lower anchor rods of the double anchored system together compared to the almost equivalent cross sections obtained experimentally.

The experimental results are in agreement with the numerical analysis to a large extent.

\section{Simplified approaches for designing double anchored sheet pile}

Due to the absence of a similar condition of a double anchored sheet pile system in the Egyptian Code which is considered to be a statically indeterminate structure, this study submitted solutions to solve this problem via three simplified approaches. The approaches are based mainly on the experimental results.

\subsection{First approach}

This approach deals with the double anchored sheet pile wall as a continuous beam on four supports: the upper and the lower anchors, the point of contra flexure, and the sheet pile tip. Figure 9 illustrates the statical system of the sheet pile wall according to this approach. The distribution of earth pressure resulting from gravity effect and that developed as a result of surcharge loads are shown in Figures 9 (a) and 9 (b), respectively. Where $\mathrm{h}$ is the free height of the double anchored sheet pile wall as shown in Figure 9.

The lateral pressure induced due to surcharge loads $(\sigma)$ is calculated as follows:

$\sigma=\mathrm{k}_{\mathrm{a}} * \mathrm{q}_{1}$

which,

$\mathrm{q}_{1}=\mathrm{q} * \mathrm{~m} /(\mathrm{m}+2 \mathrm{n})$

where:

$\mathrm{q}_{1}$ : is a portion of the surcharge, $\mathrm{q}$.

$\mathrm{m}$ : is the width of the surcharge loading.

$\mathrm{n}$ : is the free distance between the edge of surcharge and the sheet pile wall.

The active earth pressure at the dredge line $\left(\mathrm{p}_{1}\right)$ the distance (a) and the passive earth pressure $\left(\mathrm{p}_{2}\right)$ defined in Figure 9 (a) are calculated from the experimental model as follows:

$$
\begin{aligned}
& \mathrm{p}_{1}=\gamma \mathrm{h} * \mathrm{k}_{\mathrm{a}} \\
& \mathrm{a}=\mathrm{p}_{1} / \gamma\left(\mathrm{k}_{\mathrm{p}}-\mathrm{k}_{\mathrm{a}}\right) \\
& \mathrm{p}_{2}=\gamma \mathrm{b}\left(\mathrm{k}_{\mathrm{p}}-\mathrm{k}_{\mathrm{a}}\right)
\end{aligned}
$$


The principle of superposition was used to combine the earth pressure shown in Figure 9 (a) and that induced after placing a surcharge value of $10 \mathrm{kN} / \mathrm{m}^{2}$. The reactions at both the upper and the lower anchor rods, in addition to the maximum bending moment value induced in this statically indeterminate beam were assessed. As the sheet pile in this approach is assumed to be a statically indeterminate beam, the solution could be obtained using a structural analysis computer program such as SAP or other similar programs [12]. The use of numerical analysis in the design of sheet pile walls is considered to be an effective procedure [5].

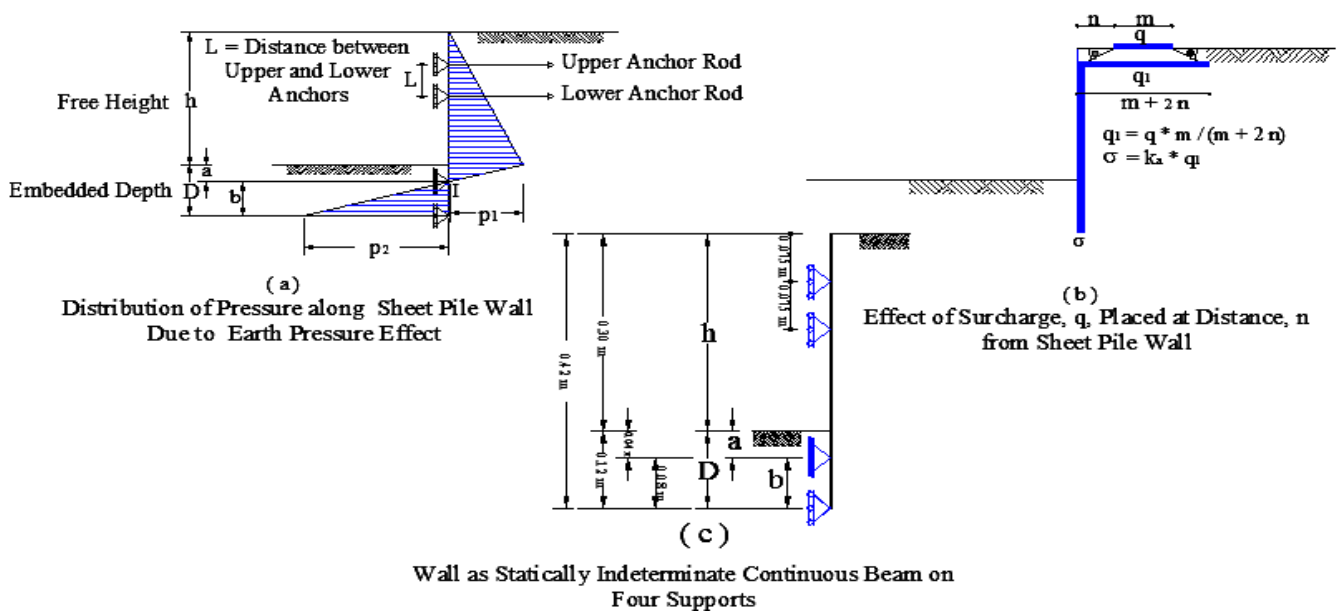

Fig. 9. First Approach of Designing Double Anchored Sheet Pile as a Statically Indeterminate Beam on Four Supports

\subsection{Second approach}

This approach divides the sheet pile wall into two beams, the upper and the lower beam. The point of division is the point of contra flexure, I, as shown in Figure 10 (a). The point $I$ is considered to be located at the point of zero pressure. The upper and the lower beams with the distributed loads resulting from both the earth pressure and the surcharge loads are shown in Figures 10 (a) and 10 (b), respectively. The earth pressure envelope, the values of earth pressure at the dredge line, $\mathrm{p}_{1}$, and the distance, $\mathrm{a}$, for the upper beam are calculated as for the first approach according to Equations 8 and 9. The lateral pressure induced due to a surcharge load, $\sigma$, is calculated according to Equation 7. In this approach, an equivalent single anchor rod is assumed to replace the two anchor rods. The equivalent anchor rod is located at the middle point between the upper and the lower anchors. The upper beam rests on two supports as shown in Figure 10 (a). It is a simply supported and statically determinate beam. The first support is located at the equivalent anchor rod and the second support at the point of contraflexure, I. Accordingly, the anchor force in the equivalent anchor rod in addition to the reaction, $\mathrm{R}$, at the second support could be calculated directly without the need of a structural program. The principle of superposition is used to combine the earth pressure shown in Figure 10 (a) and that developed after placing the surcharge as shown in Figure 10 (b).

The lower beam could be solved easily as a simply supported beam subjected to earth pressure and lateral pressure resulting from the surcharge loads, as shown in Figures 10 (a) and 10 (b). The net passive earth pressure, $\mathrm{p}_{2}$, and the uniform lateral pressure developed due to surcharge loads, $\sigma$, are calculated according to Equations 7, 8, and 10. The principle of superposition is also applied to combine the two pressures. Considering the reaction, R, transmitted from the upper beam to the lower one, the distance, $\mathrm{b}$, of the lower beam could be calculated as follows: 


$$
\mathrm{b}=\sqrt{\frac{6^{*} R}{\gamma\left(k_{p}-k_{a}\right)}}
$$

As the values of distance, a, for the upper beam and the distance, $b$, of the lower beam are calculated according to Equations 9 and 11, the total embedded depth, D, is calculated as following:

$\mathrm{D}=\mathrm{a}+1.2 * \mathrm{~b} \quad$ (12) (the vertical distance , b, was increased by $20 \%$ for practical purposes in the field)

The anchor force at the first support is divided between the upper and lower anchors according to the experimental results. One-third of the obtained anchor force value is assigned to the upper anchor rod, while two-thirds of the calculated value is assigned to the lower anchor rod.

\subsection{Third approach}

Figure 11 illustrates the third approach, which is similar to the second approach, except for the position of the equivalent anchor rod. In this approach, the equivalent anchor rod is assumed to be located at two-thirds the distance between the original upper and lower anchor rods. The position of the equivalent anchor rod is measured from the original upper rod. The computed force developed in the equivalent anchor rod is divided using the same manner adopted in the second approach. The results of the third approach are obtained using the same procedures and equations of the second approach.

\section{Comparison between anchor forces according to the three approaches}

Table 2 contains the values of anchor forces calculated according to the three approaches. The values are compared with those obtained experimentally. The table indicates that the third approach could be considered to provide the most reliable solution. The results of the third approach are close to those obtained experimentally. Experimentally, the effect of the surcharge loads on the sheet pile wall was significant even when the surcharge was placed at the remote distance of about $2 \mathrm{~h}(60 \mathrm{~cm})$. From this point of view, the experimental results support the third approach.

\section{Comparison between maximum bending moments according to the three approaches}

Table 3 contains the values of the maximum bending moments induced in the double anchored sheet pile according to the three approaches. The maximum bending moments are calculated for the case of a surcharge of $10 \mathrm{kN} / \mathrm{m}^{2}$ placed on the backfill surface of the soil at different distances from the wall. The values are compared with those obtained experimentally. The experimental work indicates that the results of the three approaches are conservative. The comparison between the results of the three approaches and those of the experimental work indicates that the third approach could be considered to provide a safe and reliable solution for both the anchor forces and the maximum bending moment. The third approach results are close to those of the experimental work, in spite of its conservative results for the maximum bending moments. In the meantime, this approach is characterized by its simplicity and applicability. In addition, the experimental work proved that even when the surcharge loads was placed at the farthest distance of about $2 \mathrm{~h}(60 \mathrm{~cm})$, the sheet pile wall was affected. The experimental results sustain the third approach that could be used in preliminary design of the double anchored sheet pile wall. 
Dina A. Emarah et al., Comparison between single and double anchored sheet piles with

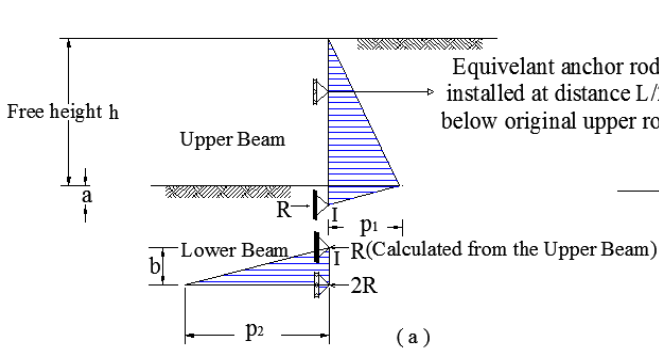

Distribution of Earth Pressure along Upper and Lower Beams of Sheet Pile Wall

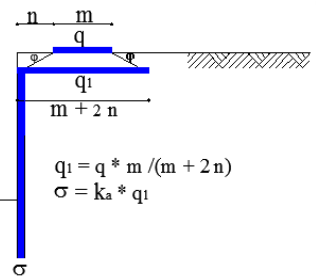

(b)

Effect of Surcharge, q, Placed at Distance n from Sheet Pile Wall

Fig. 10. Second Approach of Designing Double Anchored Sheet Pile as Two Statically Determinate Simple Beams each on Two Supports with an Equivalent Anchor Rod Installed at Distance L/2 below Original Upper Rod

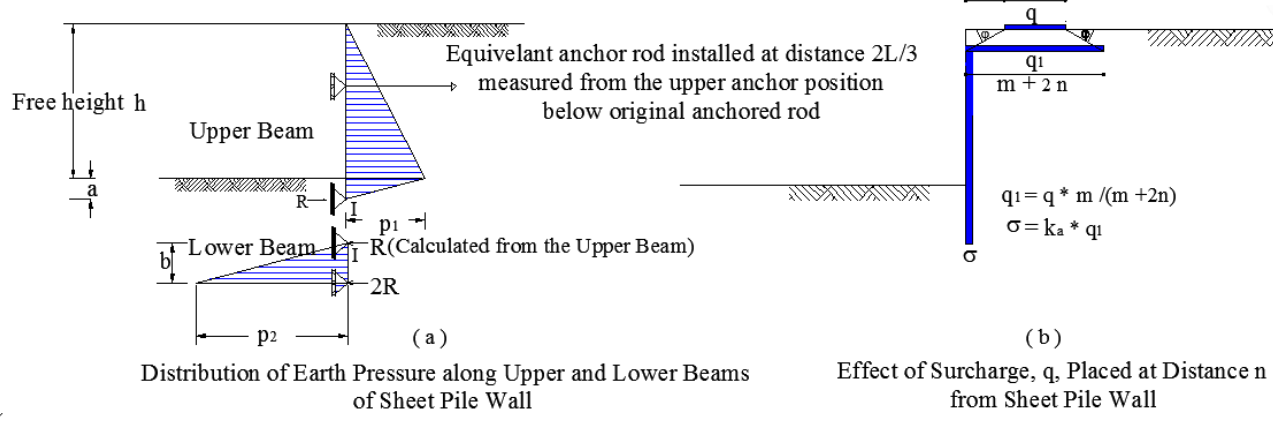

Fig. 11. Third Approach of Designing Double Anchored Sheet Pile as Two Statically Determinate Simple Beams each on Two Supports with an Equivalent Anchor Rod Installed at Distance 2L/3 below Original Upper Rod

Table 2.

Experimental and Analytical Anchor Forces in Case of Double Anchored Wall After Placing a $10 \mathrm{kN} / \mathrm{m}^{2}$ Surcharge at Different Distances from Wall

\begin{tabular}{|c|c|c|c|c|c|}
\hline \multirow{2}{*}{ Surcharge Position } & Anchor Position & \multicolumn{4}{|c|}{ Anchor Forces $\left(* 10^{-3} \mathrm{kN}\right)$} \\
\cline { 3 - 6 } & & $\begin{array}{c}\text { First } \\
\text { Approach }\end{array}$ & $\begin{array}{c}\text { Second } \\
\text { Approach }\end{array}$ & $\begin{array}{c}\text { Third } \\
\text { Approach }\end{array}$ & $\begin{array}{c}\text { Experimental } \\
\text { Results }\end{array}$ \\
\hline \multirow{2}{*}{$5 \mathrm{~cm}(\mathrm{~h} / 6)$} & Upper Anchor & 18.78 & 18.8 & 19.2 & 21.3 \\
\cline { 2 - 6 } & Lower Anchor & 40.6 & 37.2 & 38.4 & 42.6 \\
\hline \multirow{2}{*}{$10 \mathrm{~cm}(\mathrm{~h} / 3)$} & Upper Anchor & 10.8 & 14.85 & 15 & 20.3 \\
\cline { 2 - 6 } & Lower Anchor & 36 & 29.7 & 30 & 40.22 \\
\hline \multirow{2}{*}{$20 \mathrm{~cm}(0.5 \mathrm{~h})$} & Upper Anchor & 3.1 & 12 & 12.2 & 12.33 \\
\cline { 2 - 6 } & Lower Anchor & 31.8 & 24 & 24.4 & 30.4 \\
\hline \multirow{2}{*}{$30 \mathrm{~cm}(\mathrm{about} \mathrm{h})$} & Upper Anchor & 1.8 & 10.8 & 10.6 & 9.46 \\
\cline { 2 - 6 } & Lower Anchor & 28.5 & 21.6 & 21.2 & 27.2 \\
\hline & Upper Anchor & 1.1 & 7.7 & 7.7 & 7.22 \\
\cline { 2 - 6 } & Lower Anchor & 22.8 & 15.4 & 15.4 & 17.35 \\
\hline \multirow{2}{*}{$40 \mathrm{~cm}\left(1^{1 / 3} \mathrm{~h}\right)$} & Upper Anchor & 1.74 & 6 & 6.8 & 6.7 \\
\cline { 2 - 6 } & Lower Anchor & 20.3 & 12 & 13.6 & 13.37 \\
\hline $60 \mathrm{~cm}($ about $2 \mathrm{~h})$ & Upper Anchor & 2.84 & 5.08 & 6 & 2.53 \\
\cline { 2 - 6 } & Lower Anchor & 16.3 & 10.16 & 12 & 5.11 \\
\hline
\end{tabular}


Table 3.

Experimental and Analytical Maximum Bending Moments in Double Anchored Wall After placing a $10 \mathrm{kN} / \mathrm{m}^{2}$ Surcharge at Different Distances from Wall

\begin{tabular}{|c|c|c|c|c|}
\hline \multirow{2}{*}{$\begin{array}{l}\text { Surcharge } \\
\text { Position }\end{array}$} & \multicolumn{4}{|c|}{ Maximum Bending Moments $\left(* 10^{-5} \mathrm{kN} . \mathrm{m}\right)$} \\
\hline & $\begin{array}{c}\text { First } \\
\text { Approach }\end{array}$ & $\begin{array}{l}\text { Second } \\
\text { Approach }\end{array}$ & $\begin{array}{c}\text { Third } \\
\text { Approach }\end{array}$ & $\begin{array}{l}\text { Experimental } \\
\text { Results }\end{array}$ \\
\hline $5 \mathrm{~cm}(\mathrm{~h} / 6)$ & 74 & 91.5 & 88 & 56.43 \\
\hline $10 \mathrm{~cm}(\mathrm{~h} / 3)$ & 62 & 89.2 & 75.5 & 52.37 \\
\hline $15 \mathrm{~cm}(0.5 \mathrm{~h})$ & 58.3 & 82.7 & 68.8 & 49.66 \\
\hline $20 \mathrm{~cm}(2 \mathrm{~h} / 3)$ & 51.8 & 78.8 & 62 & 42.11 \\
\hline $30 \mathrm{~cm}$ (about h) & 44.7 & 72.6 & 58.4 & 25.34 \\
\hline $40 \mathrm{~cm}\left(11^{1} / 3 \mathrm{~h}\right)$ & 40 & 63.5 & 53.5 & 15.4 \\
\hline $60 \mathrm{~cm}$ (about $2 \mathrm{~h}$ ) & 29.8 & 60.5 & 44.7 & 12.5 \\
\hline
\end{tabular}

\section{Conclusions}

The main conclusions drawn from this study are as follows:

1. The closer the surcharge load to the sheet pile wall, the higher the maximum bending moment values and the anchor forces developed in the sheet pile wall are.

2. The use of double anchored sheet pile instead of single anchored one resulted in a large decrease in the value of maximum bending moment. The largest reduction occurs when the surcharge load is placed at the closest distance from the sheet pile wall. This reduction reached about $82 \%$ of the maximum moment in single anchored sheet pile. This is due to the existence of two rows of anchor rods constituting two supports for the system instead of one, in addition to the shorter distance between the lower anchor and the dredging line.

3. For all cases of surcharge loading in the double anchored system, the lower anchor force is larger than the upper anchor force. For the configuration under consideration, the forces developed in the lower anchor rods are always higher than those developed in the upper anchor rods. This is because the lower anchor force consists of the reaction to an upper span common with the upper anchor and a larger lower span supporting a higher lateral pressure. However, the upper anchor force consists of a smaller reaction to the upper common span and the upper cantilever portion of the sheet pile wall where the lateral pressure has relatively small value.

4. When the double anchored sheet pile is used instead of single anchored one, the values of maximum bending moments, anchor forces are reduced significantly. The reduction decreases as the free distance between edge of surcharge and sheet pile wall increases up to a distance of about the free height of wall, $h$. Then the reduction increases when the free distance reaches about twice the free height of wall $(2 \mathrm{~h})$, i.e. just beyond the anchor plate position. After placing the surcharge at this distance, the anchor force is reduced and the maximum bending moment in the sheet pile wall is increased.

5. Three approaches have been investigated as simplified solutions for determining maximum bending moments and anchor forces in double anchored sheet pile wall. The sheet pile wall could be considered as a statically indeterminate continuous beam supported on four supports or as two statically determinate beams with an equivalent 
anchor rod. The third approach could be used in designing the double anchored sheet pile as it provides the most reliable solution and results.

6. In the current study, the results of the simplified approaches were found to be closer to the experimental results when the lateral pressure was calculated based on a surcharge loading distribution at an angle of $\varphi$ with the horizontal instead of an angle of $45^{\circ}$ according to the elastic theory.

\section{Recommendations}

1. It is recommended to execute further studies using double anchor sheet pile using different types of sand in order to achieve a simplified solution for the statically indeterminate structure in all types of sand.

2. It is recommended to study the effect of changing the position of the upper and lower anchor rod with relative to each other to assess the optimum position which produces the minimum values of anchor forces and bending moments.

\section{REFERENCES}

[1] L. Bjerrum, CJF. Clausen and JM. Duncan, "Earth pressures on flexible structures," 5th uropean conference on soil mechanics and foundation engineering, Vol. 2, pp. 169-96, 1972.

[2] K. Krabbenhoft, L. Damkilde and S. Krabbenhoft, "Ultimate limit state design of sheet pile walls by finite elements and nonlinear programming," Comput Struct, Vol. 83, No.4, pp. 383-93, 2005.

[3] Y. Tan and SG. Paikowsky, "Performance of sheet pile wall in peat," ASCE J Geotech Geoenviron Eng, Vol.134, No. pp.4445-58, 2008.

[4] DM. Potts and AB. Fourie, "The behavior of a propped retaining wall: results of a numerical experiment," Geotechnique, Vol. 34, No. 3, pp. 383-404, 1984.

[5] O. Bilgin, "Numerical studies of anchored sheet pile wall behavior constructed in cut and fill conditions," Computers and Geotechnics, Vol. 37, pp. 399-407, 2010.

[6] J.E. Bowles, "Foundation Analysis and Design," Mc Graw-Hill Company, Inc., London, England, 1996.

[7] J.N. Cernica, "Geotechnical Engineering: Soil Mechanics," John Wiley \& Sons, Inc., New York, U.S.A, 1998.

[8] P.W. Rowe, "Anchored Sheet Pile Walls," Institution of Civil Engineers, Britain, Vol.1, No. 5788, pp.27-70 \& pp.616-619, 1952.

[9] K.R. Arora, "Soil Mechanics and Foundation Engineering," Nai Sarak, Delhi, India, 1987.

[10] Egyptian Code of Soil Mechanics and Foundation Design and Constructions, "Laboratory Experiments," Ministry of Housing, Vol. 2, pp.205-207, 2012.

[11] Egyptian Code of Soil Mechanics and Foundation Design and Constructions, "Retaining Walls," Ministry of Housing and Utilities, Cairo, Vol.7, pp. 18-22, 2012.

[12] N. Kumar and A* Dey, "Behavior of Rigid Cantilever Sheet Pile Walls: Numerical and Finite Element Analysis,” Netherlands, Indian geotechnical conference, pp.18-20, 2014. 
674

JES, Assiut University, Faculty of Engineering, Vol. 44, No. 6, November 2016, pp. 659-674

\section{مقارنة بين الستائر اللوحية الأحادية و المزدوجة الأربطة \\ باستخدام طرق مبسطة لحل الأنظمة غير المحددة إستاتيكاً}

\section{ملخص البحث}

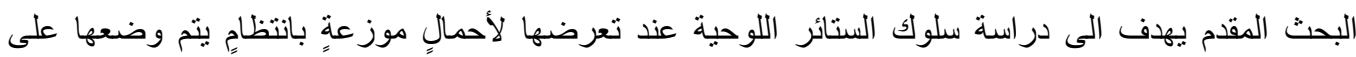

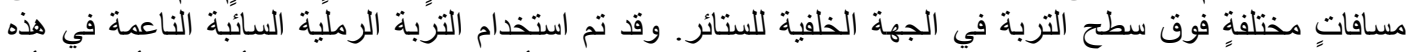

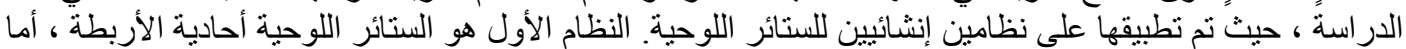

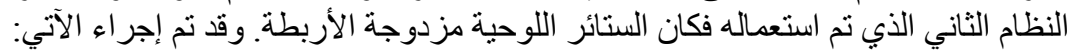

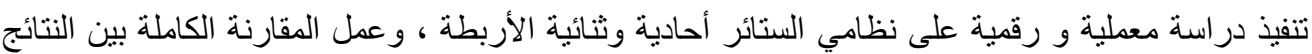

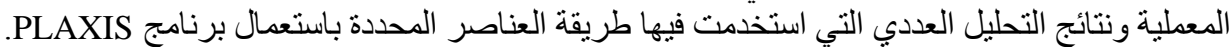

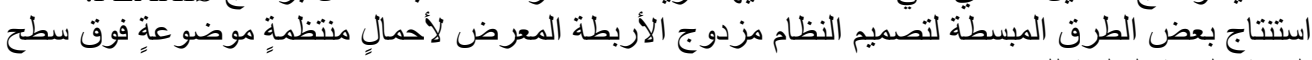
التربة بالجهة الخلفية للستارة.

الإستنتاجات

• أثتبت النتائج التى تم الحصول عليها معملياً ورقياً أن القوة المتولدة فى الرباط الأحادي (الستارة أحادية الرباط)

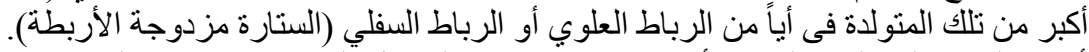

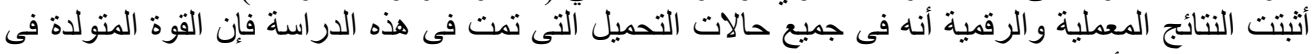

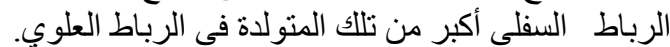

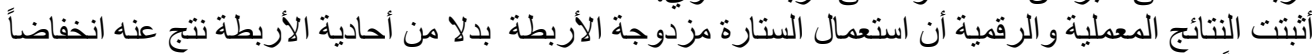

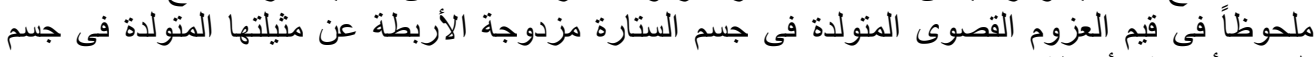
الستارة أحادية الأربطة.

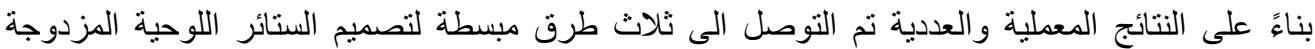

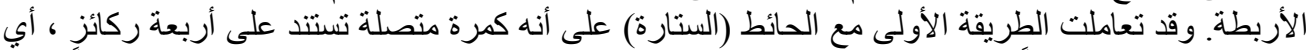

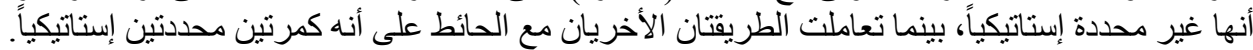

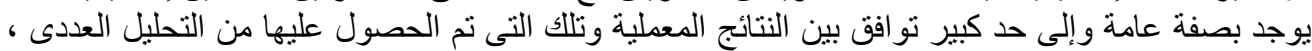

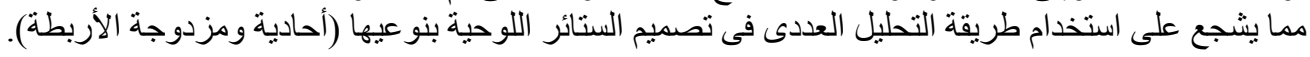

